\title{
Exotic parrots breeding in urban tree cavities: nesting requirements, geographic distribution, and potential impacts on cavity nesting birds in southeast Florida
}

\author{
Joshua M. Diamond* (10 and Michael S. Ross
}

\begin{abstract}
Background: Exotic parrots have established breeding populations in southeast Florida, including several species that nest in tree cavities. We aimed to determine the species identity, nest site requirements, relative nest abundance, geographic distribution, and interactions of parrots with native cavity-nesting bird species.

Methods: We searched Miami-Dade County, Florida, and nearby areas for natural cavities and holes excavated by woodpeckers, recording attributes of potential nest trees. We inspected all cavities with an elevated video inspection system to determine occupancy by parrots or other birds. We mapped nearly 4000 citizen science observations of parrots in our study area corresponding to our study period, and used these to construct range maps, comparing them to our nesting observations.

Results: Not all parrots reported or observed in our study area were actively breeding. Some parrots were observed at tree cavities, which previous studies have suggested is evidence of reproduction, but our inspections with an elevated video inspection system suggest they never initiated nesting attempts. Several parrot species did successfully nest in tree cavities, Red-masked Parakeets (Psittacara erythrogenys) and Orange-winged Parrots (Amazona amazonica) being the most common ( $n=7$ and 6 nests, respectively). These two parrots had similar nesting requirements, but Orange-winged Parrots use nests with larger entrance holes, which they often enlarge. Geographic analysis of nests combined with citizen science data indicate that parrots are limited to developed areas. The most common parrots were less abundant cavity nesters than the native birds which persist in Miami's urban areas, and far less abundant than the invasive European Starling (Sturnus vulgaris).

Conclusions: Exotic parrots breeding elsewhere in the world have harmed native cavity-nesting birds through interference competition, but competitive interference in southeast Florida is minimized by the urban affinities of parrots in this region. The relative abundance and geographic distribution suggest that these parrots are unlikely to invade adjacent wilderness areas.
\end{abstract}

Keywords: Amazona, Cavity nest webs, Invasive species, Parakeets, Psittacara, Urban ecology

\section{Background}

Southeast Florida is a global hotspot for invasive exotic fauna of all sorts, including birds (Simberloff et al. 1997; Sementelli et al. 2008; Mutascio et al. 2018;

*Correspondence: jdiam009@fiu.edu

Florida International University, Earth \& Environment, Miami, FL 33199, USA
Clements et al. 2019). Some of these non-native species have invaded protected wilderness in Everglades National Park, threatening the native biota (Doren and Jones 1997; Dorcas et al. 2012). Other species have taken advantage of the sprawling urban area and its exotic tropical vegetation. Miami-Dade County, Florida is the most densely developed section of the region, which continues north to Broward and Palm Beach Counties. The Miami area 
has a well-documented exotic avifauna, including waterbirds, passerines, and parrots (Owre 1973; James 1997; Avery and Moulton 2007; Blackburn and Cassey 2007). Parrots (Aves: Psittaciformes) are primarily tree-cavity nesting species (Cameron 2012). As a member of the cavity-nesting guild, they compete for suitable nest cavities with a variety of native and exotic birds, including the woodpeckers which make the best nest sites (Martin and Eadie 1999; Cornelius et al. 2008; Blackburn et al. 2009; Orchan et al. 2012; Menchetti and Mori 2014). Most research on the role of exotic parrots in cavity nest webs has been conducted on Rose-ringed Parakeets (Psittacula krameri) in Europe, which compete with native birds and mammals for nest cavities (Runde et al. 2007; Strubbe and Matthysen 2007, 2009; Czajka et al. 2011; Newson et al. 2011; Mori et al. 2013, 2017; Hernández-Brito et al. 2014, 2018; Peck et al. 2014). This research has generally concluded that the Rose-ringed Parakeet has reduced populations of native species though interference competition. This parrot is not a breeding resident in southeast Florida, but several other parrot species are participants in cavity nest webs in Miami, using woodpecker holes for reproduction.

Previous research has identified Miami-Dade County, Florida as a critical research area for the establishment of exotic parrot species, in part because of their high species richness in the area (Pranty and Epps 2002). More parrot species are observed in Miami than have established breeding populations, several of which have not joined the tree cavity-nesting guild. Some parrot species do not breed readily in southeast Florida but persist because of a high introduction effort of escaped or released pets. Other parrots use nest sites other than the tree nests we studied. The goals of our study were (1) to identify species of exotic parrots that breed in tree nest cavities, (2) to compare the nesting requirements of the most common parrot species, (3) to compare the abundance of parrot nests found in trees vs. nests of other cavity-nesting birds, and (4) to determine if, based on their relative abundance, geographic distribution, and interactions with other cavity-nesting birds, tree-nesting parrots pose a threat to the native cavity nesting guild in natural areas outside of the urban matrix. We predicted that the parrot species successfully breeding in tree cavities would be a subset of the species observed and reported in citizen science databases; although, we were unsure which species would be most common. We predicted parrot nests would be less common than other cavity-nesting birds and that if their ranges were compact and restricted to urban areas, they would have minimal interaction with native species, but interactions would be more frequent if we found parrot nests in the Florida Everglades.

\section{Methods}

Our study area encompassed Miami-Dade County, Florida, as well as surrounding urban and natural areas in Fort Lauderdale, Everglades National Park, and the upper Florida Keys. We searched urban, suburban, and rural developed areas, as well as pine rockland forests, tropical hardwood hammocks, recreational parklands, botanical gardens, coastal mangrove forests, freshwater and estuarine wetlands, and other habitat types found within the study region. Data collection began at the end of the 2016 breeding bird season, and continued through two full breeding seasons until October 2018. We searched roughly alternating days in urban areas and natural settings, searching for nests up to eight hours per day. Within urban areas, we did not expend more search area in areas with parrots reported through citizen science platforms. We did search for specific nest or roost trees reported or photographed by citizen scientists.

We located and monitored cavity nests following the field protocol established by the United States Forest Service (Dudley et al. 2003). We adapted these methods developed for temperate montane forests to search for cavity nests in a flat, tropical, urban region. Our searches were almost exclusively visual, inspecting any dead trees we could find, or trees that contained limbs or sections with obvious decay. We used visual cues such as discolored wood, fungal fruiting bodies of Ganoderma spp., or woodchips below the nest to indicate potential nest trees. We recorded potential nest trees if they contained at least one cavity entrance, primarily round entrances excavated by woodpeckers, but also natural cavities and irregularly shaped cavities that woodpeckers excavated but parrots subsequently enlarged. Within the urban matrix, a mosaic of property ownership and uses hindered our ability to completely survey for nests. We surveyed along the public right-of-way in urban areas, such as sidewalks, road medians, swales, and urban greenspaces. We used a random walk search in these areas, and primarily located nest cavities by bicycle, although we also used a motor vehicle to reach nests beyond the central urban core of the study area. The random walk technique allowed for maximum observer safety when searching for nests by bicycle in a busy metropolitan area. In order to inspect as many sites as possible, few locations were visited more than once every 2 weeks, although active parrot nests were visited approximately once per week. Our searches in wilderness setting of Everglades National Park and large adjacent conservation areas were limited to also publically accessible areas, but we used both roads and pedestrian trails to search for nests with the same random walk pattern as in urban areas. 
Previous studies of parrots in South Florida have assessed the breeding population of various species based on citizen-science observational records or based on breeding observations from the ground (Pranty and Epps 2002; Avery and Moulton 2007; Pranty et al. 2010; Pranty and Lovell 2011). This project differed by inspecting all tree cavities found in the region, not just cavities where we expected to find breeding parrots. Ground-based visual surveys of cavities have been demonstrated to detect a low proportion of active secondary-cavity nesting bird nests (Ouellet-Lapointe et al. 2012). It may also describe parrot pairs exploring or roosting in tree cavities as suspected breeders, without evidence of eggs or nestlings. We inspected all tree cavities to accurately record the status of active parrot nests and to provide a comparison to the nests of other cavity-nesting birds. We recorded the following attributes for each nest tree: tree species, diameter at breast height (DBH), total tree height, and decay class. Decay class was estimated for snags on a scale from one to nine where decay class one appeared recently dead and stable, and decay class nine appeared unsteady and ready to fall. We did not estimate decay class for other surveyed cavity nesting sites, i.e., live trees and utility poles. We inspected the interior of tree nest cavities using a wireless video camera designed for the study of cavity-nesting birds (Fig. 1, Luneau and Noel 2010). We used two wireless cavity inspection cameras to record still images and videos inside nests (Treetop Peeper version 3.2 and 3.3). We mounted the cameras on a collapsible fiberglass pole capable of reaching up to $15 \mathrm{~m}$ (Crain telescoping measuring rod, model 90182). We used the pole to measure the height of nest trees and entrance holes. Cavity inspection images were used to estimate the internal diameter and internal depth of nests.

We completed all statistical analyses using IBM SPSS version 20.0 and geographic analysis in ArcMap GIS version 10.4. We used t-tests to compare mean attributes of Red-masked Parakeet and Orange-winged Parrot nests. We recorded the location of all nest trees using a portable GPS unit (Garmin GPSmap 62s). We mapped nearly 4000 citizen science observations reported to eBird from 2016 to 2018 for geographic range analysis, corresponding to the duration of our field study. We constructed range maps for exotic parrots in our study area by drawing minimum convex polygons around reported observations. Our polygons include at least $96 \%$ of observations of each parrot in the study area, removing errant observations outside of the core range of each species.

\section{Results}

We recorded the use of tree cavities by seven species of parrots in our study area. Of these, we observed active breeding attempts by four species, the Orange-winged
Parrot, Red-masked Parakeet, Nanday Parakeet (Aratinga nenday), and Blue-and-yellow Macaw (Ara ararauna). We observed tree cavity use, but could not confirm active breeding attempts by the Blue-crowned Parakeet (Thectocercus acuticaudatus), Scarlet-fronted Parakeet (Psittacara wagleri), and the Chestnut-fronted Macaw (Ara severus).

We recorded 23 cavity nest sites used by parrots during our study period (Table 1). All nest sites were excavated by woodpeckers, although parrots had enlarged one-third of cavity entrances. Some nest trees had broken tops which were open from above, but all contained woodpecker holes, which were observed as the primary entrances and exits of the nest. Of thirteen active parrot cavity nests found (Table 2), only five were initially observed from the ground. The remaining eight nests were discovered upon inserting the nest camera, suggesting the importance of cavity nest video inspections for assessing breeding populations of parrots. Nearly all cavity nest sites $(91.2 \%)$ were in palm trees, $87.5 \%$ in the royal palm (Roystonea regia). The remaining nest sites were made in wood utility poles, formerly pine trees, shaped and treated to inhibit decay. Across our study region, palm trees were particularly important to cavitynesting birds, and $63.1 \%$ of 967 trees excavated by woodpeckers were palms. In developed areas, where parrots are most common, $83.0 \%$ of excavated trees were palms. The royal palm is the most common tree excavated by woodpeckers in the region, representing $28.0 \%$ of all woodpecker nest trees. Parrots only used $2.4 \%$ of nest trees in our study.

Two-thirds of the nest trees used by parrots were excavated by Red-bellied Woodpeckers (Melanerpes carolinus), and one-third were excavated by Pileated Woodpeckers (Dryocopus pileatus). The Red-bellied Woodpecker is the main excavator of cavities of this region, creating $78.1 \%$ of all cavities $(n=1864)$. The Pileated Woodpecker only excavated $16.0 \%$ of nests in this region, many of which were outside of the urban matrix where parrots are most often observed. Active breeding attempts of Pileated Woodpeckers were more common in Everglades National Park and the surrounding rural areas. The parrot species observed in the region are almost never reported within Everglades National Park or other major conservation areas and are restricted almost exclusively to the developed matrix. Pileated Woodpecker cavities excavated in urban parks and botanical gardens were the most likely to be used by parrots. The Northern Flicker (Colaptes auratus) excavated few cavities within the breeding ranges of parrots, and cavities excavated by Downy Woodpeckers (Picoides pubescens) were uncommon and too small for parrots. Parrots used cavities excavated by Red-bellied Woodpeckers primarily 


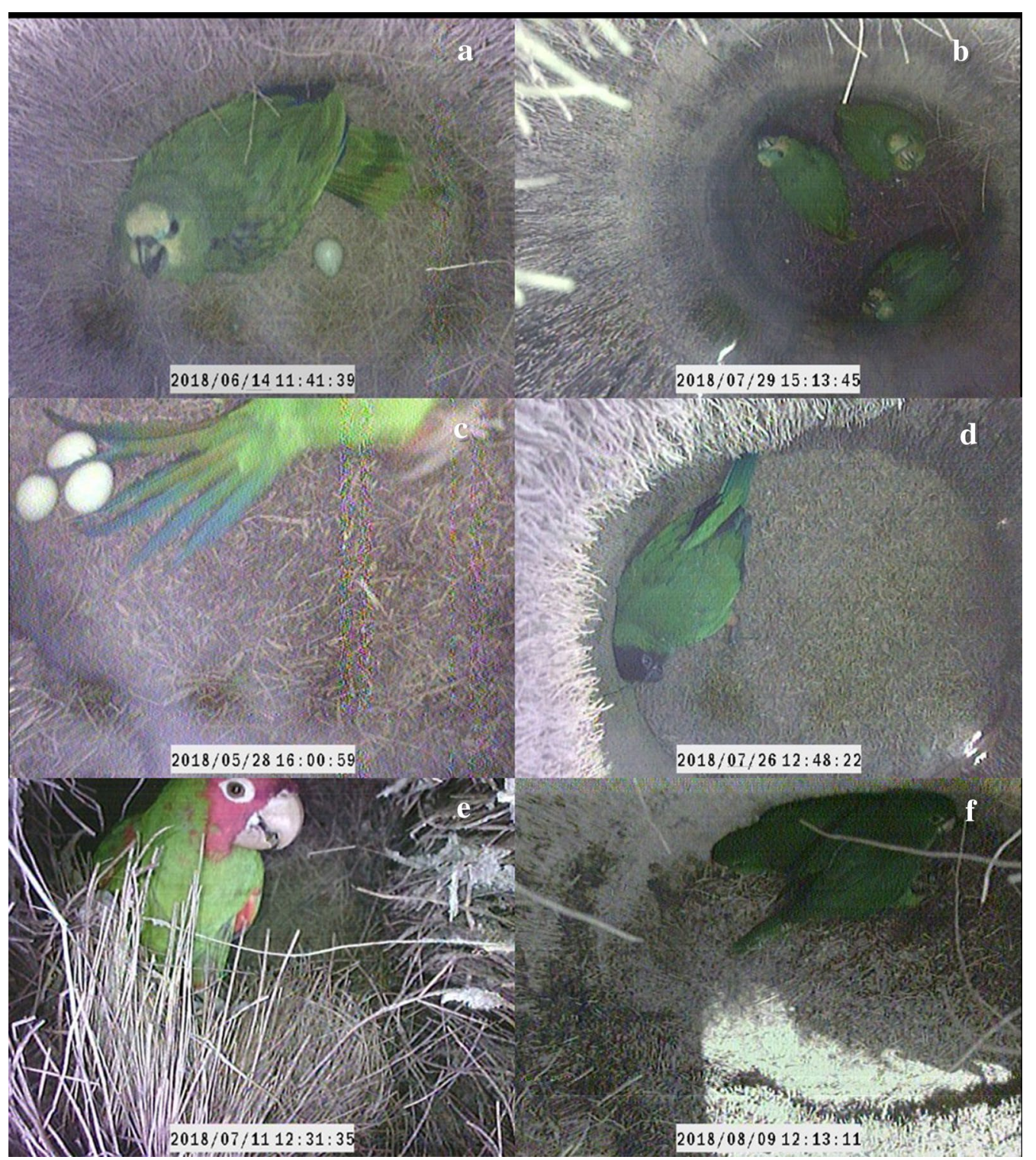

Fig. 1 Parrots nesting in tree cavities. Orange-winged Parrot incubating eggs (a) and near fledglings (b). Nanday Parakeet eggs visible behind tail feathers (c) and near fledgling (d). Red-masked Parakeet guarding eggs (e) and near-fledglings (f)

in more densely developed areas where Pileated Woodpecker cavities are less common. Parrots enlarged Redbellied Woodpecker entrance holes $53.3 \%$ of the time, but only enlarged a Pileated Woodpecker hole in one of eight cases.

Nests of Orange-winged Parrots and Red-masked Parakeets, the most numerous parrot species breeding in tree cavities, were similar in most attributes. The height of trees used for nesting by Orange-winged Parrots $(10.4 \pm 4.4 \mathrm{~m})$ was not significantly different from Red-masked Parakeets $\left(11.1 \pm 4.0 \mathrm{~m}, t_{11}=-0.3\right.$, $p=0.764)$. The DBH of trees used for nesting was not significantly different $(34.7 \pm 5.2 \mathrm{~cm}$ vs. $36.9 \pm 4.6 \mathrm{~cm}$, $\left.t_{11}=-0.8, p=0.434\right)$. The decay class of the tree used for nesting (score assessed 1-9) was not significantly different $\left(2.2 \pm 0.8\right.$ vs. $\left.3.7 \pm 1.5, t_{10}=-1.6, p=0.133\right)$. The height of the nest entrance hole above the ground surface was not significantly different $(8.8 \pm 3.2 \mathrm{~m}$ vs. $\left.9.3 \pm 4.5 \mathrm{~m}, t_{11}=-0.3, p=0.752\right)$. Diameters of nest entrance holes used by the Orange-winged Parrot were larger than entrance holes used by the Red-masked Parakeet $\left(13.4 \pm 3.6 \mathrm{~cm}\right.$ vs. $\left.8.7 \pm 2.0 \mathrm{~cm}, t_{11}=3.0, p<0.05\right)$. The Orange-winged Parrot nested in cavities excavated by the larger Pileated Woodpecker or enlarged 


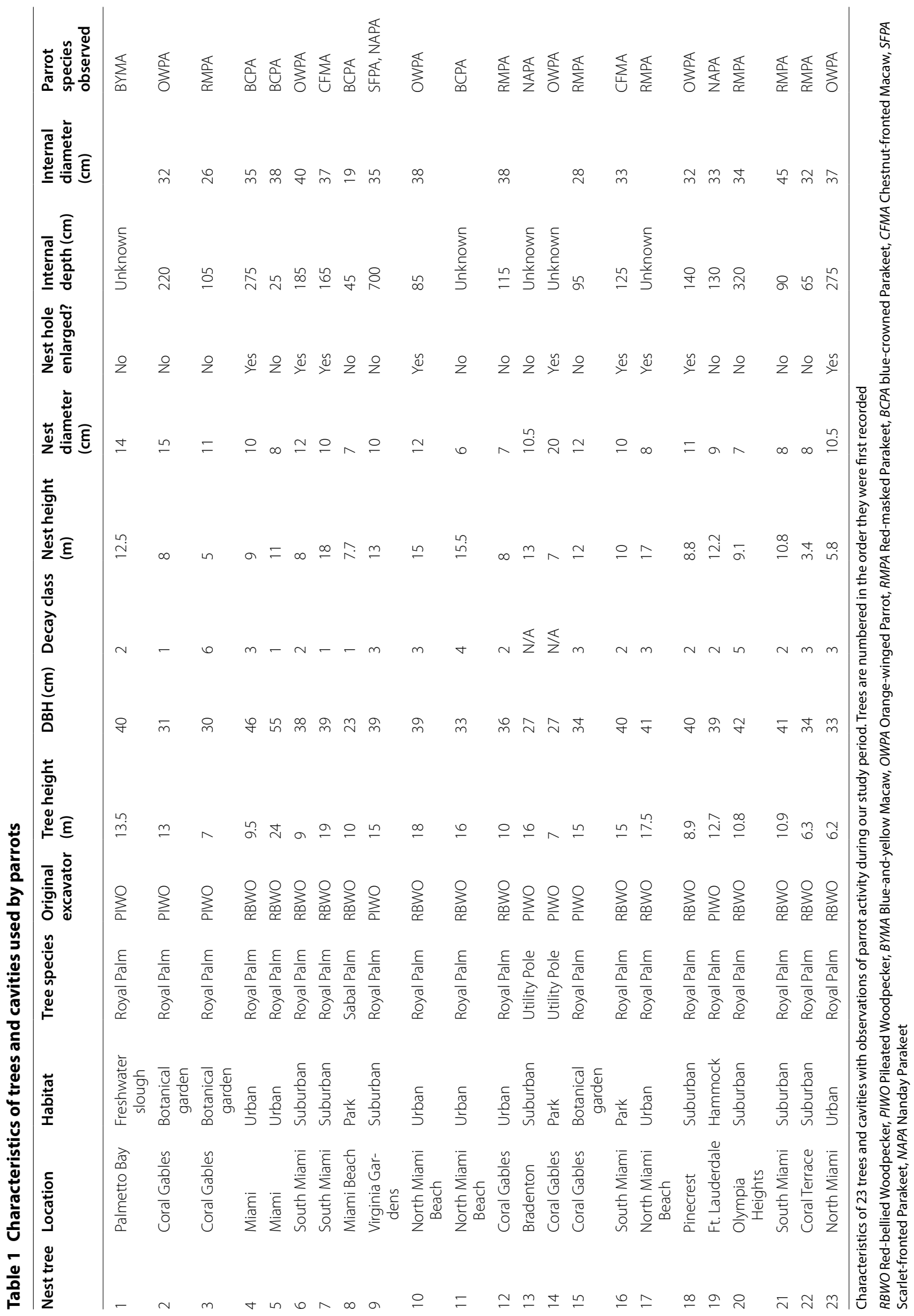


Table 2 Active nesting attempts of parrots in tree cavities

\begin{tabular}{|c|c|c|c|c|c|c|}
\hline Nest tree & Parrot species & Egg laying date & Number of eggs & Hatch date & Fledge date & Result \\
\hline 1 & BYMA & 28-Jun-16 & Unknown & 28-Jul-16 & $31-$ Oct-16 & 2 fledged \\
\hline 2 & OWPA & 20-Apr-17 & 2 & & & 2 eggs failed, egg fragments observed \\
\hline 2 & OWPA & 06-May-17 & 2 & 29-May-17 & 14-Aug-17 & 2 fledged \\
\hline 3 & RMPA & & & & & $\begin{array}{l}\text { No eggs found but repeated visits by pair during Spring } \\
2017\end{array}$ \\
\hline 6 & OWPA & 06-Apr-17 & 4 & 01-May-17 & 05-Jul-17 & 2 fledged \\
\hline 10 & OWPA & 01-May-17 & 3 & & & $\begin{array}{l}3 \text { eggs failed, eggs missing, probable raccoon preda- } \\
\text { tion based on scratches and enlargement }\end{array}$ \\
\hline 12 & RMPA & 06-Jun-17 & 1 & & & 1 egg failed, egg missing \\
\hline 18 & OWPA & 20-May-18 & 2 & & & 2 eggs failed, eggs missing \\
\hline 19 & NAPA & 24-May-18 & 3 & 17-Jun-18 & 10-Aug-18 & 1 fledged \\
\hline 20 & RMPA & 17-Jun-18 & 3 & 10-Jul-18 & 17-Aug-18 & 3 fledged \\
\hline 21 & RMPA & 08-Jun-18 & Unknown & 01-Jul-18 & 14-Aug-18 & 2 fledged \\
\hline 22 & RMPA & 16-Jun-18 & 2 & 09-Jul-18 & 20-Aug-18 & $\begin{array}{l}\text { Unclear - internal cavity shape may have allowed near- } \\
\text { fledglings to hide, probable success }\end{array}$ \\
\hline 23 & OWPA & 02-May-18 & Unknown & 27-May-18 & 05-Aug-18 & 3 fledged \\
\hline
\end{tabular}

Numbering of nest trees follows Table 1

BYMA Blue-and-yellow Macaw, OWPA Orange-winged Parrot, RMPA Red-masked Parakeet

cavities excavated by Red-bellied Woodpeckers. The Red-masked Parakeet was able to nest in some Red-bellied Woodpecker cavities without enlarging the entrance hole. The internal depth of nest cavities were not significantly different $(181.0 \pm 72.9 \mathrm{~cm}$ vs. $131.7 \pm 93.8 \mathrm{~cm}$, $\left.t_{9}=1.0, p=0.363\right)$. The internal diameters of nest cavities were not significantly different $(35.8 \mathrm{~cm} \pm 3.6 \mathrm{~cm}$ vs. $\left.33.8 \pm 6.9 \mathrm{~cm}, t_{9}=0.6, p=0.583\right)$.

Our methods were not designed to calculate a population estimate for parrot species in Miami, but in the same set of trees we recorded the number of other cavity-nesting birds breeding attempts for comparison. We observed one active nest each of Blue-and-yellow Macaw and Nanday Parakeet, six Orange-winged Parrot nests, and seven Red-masked Parakeet nests. We found thirteen active nests each for Pileated Woodpecker and Northern Flicker, and 183 active Red-bellied Woodpecker nests. We recorded 44 Eastern Screech Owl (Megascops asio) nests, making this the only common secondary-cavity nesting bird in the study region. We also observed two Great-crested Flycatcher (Myiarchus crinitus) nests, the only other native secondary-cavity nester. We found 337 European Starling nests, and eleven Common Myna (Acridotheres tristis) nests. The comparison to other native and exotic birds is important, because there are other exotic parrot species frequently observed in or near our study area, but we did not find them breeding in tree cavities. These species are either avoiding the woodpecker cavity nest web, or are primarily feral escaped or released individuals which are not breeding.

\section{Interspecific interactions}

The interactions between parrots and other cavity-nesting birds near nest cavities suggests minimal interaction with native birds. Interspecific interactions were recorded at seven of 23 parrot nest trees. The most hostile interactions were between Blue-crowned Parakeets and European Starlings. A pair of Blue-crowned Parakeets removed starling nest material from a cavity in downtown Miami, and aggressive vocal interactions and supplanting flights were recorded at another cavity nearby. Other parrots had minimal interaction with starlings. At various times, a Pileated Woodpecker roosted in a very large royal palm snag, sharing the roost with a Scarlet-fronted Parakeet and Nanday Parakeet. The central hollow of this tree was estimated to be $7 \mathrm{~m}$ deep. Other parrots shared snags with other species sequentially. An Orange-winged Parrot nested in an old Pileated Woodpecker nest in 2017, and in late March 2018 was observed inside the snag once prior to its breeding season. By the following visit in April, an Eastern Screech Owl had laid eggs in the nest, which was followed by a Red-bellied Woodpecker breeding in June. Another snag was sequentially used first by the Pileated Woodpecker and Red-bellied Woodpecker simultaneously, excavating multiple holes before the 2018 breeding season. No woodpeckers attempted to nest in this tree, instead an Eastern Screech Owl first used a Pileated Woodpecker hole as a roost, followed by a European Starling nesting attempt in a Red-bellied Woodpecker hole. A pair of Red-masked Parakeet was seen using another Pileated 
Woodpecker hole in the tree later in the season, but no eggs were observed.

The most sustained interaction between parrots and native birds started in mid-June of 2018, in a suburban neighborhood near Miami. A Red-bellied Woodpecker excavated two nests, in two royal palm snags, $3 \mathrm{~m}$ apart. By the end of June, the Red-bellied Woodpecker and a Red-masked Parakeet were each nesting in the adjacent snags simultaneously. Although the Red-masked Parakeet took one woodpecker nest, the woodpecker was able to breed successfully. The two species appeared to share alarm calls upon observers approaching the nest snags. Adult parrots and woodpeckers would perch on an adjacent tree together while nest inspections were conducted. Both nests successfully fledged offspring.

\section{Geographic range analysis}

We created polygons to encompass citizen science observations of each parrot species in the region (Fig. 2). The locations of nest and roost trees that we found closely matched the geographic ranges of these species we assessed from citizen-science data. For example, we found one tree used as a roost by the Scarlet-fronted Parakeet in Virginia Gardens, Florida. Nearly all sightings of this species have been made in Virginia Gardens and adjacent municipalities. We found three trees used by Blue-crowned Parakeets in downtown Miami and Miami Beach. Most of the sightings of this species have occurred in Miami Beach, and other adjacent urban islands such as Key Biscayne, as well as a broader area of Broward County, Florida. One Blue-and-yellow Macaw nest was observed in Palmetto Bay, within the narrow range of this species, which corresponds to the range of the population described from 2003 to 2009 (Pranty et al. 2010). We did not find any nest or roost trees outside the range of any species reported on eBird. Parrots were geographically limited to developed regions, with few/no observations of most species in major conservation areas. Parrot nest trees were found primarily in urban and suburban areas without complete cover of native vegetation. When parrots were found in natural or semi-natural settings, these were conservation areas embedded within an urban matrix, in close proximity to development.

\section{Discussion}

The species composition of exotic parrots breeding in Miami has changed over time. In the early 1990s, the Red-masked Parakeet, Nanday Parakeet, and Orangewinged Parrot were noted in Florida, but considered unlikely to persist as breeding populations (James 1997). Currently, the Red-masked Parakeet and Orange-winged Parrot are the most successful cavity-nesting parrots in Miami, while the Nanday Parakeet has the broadest

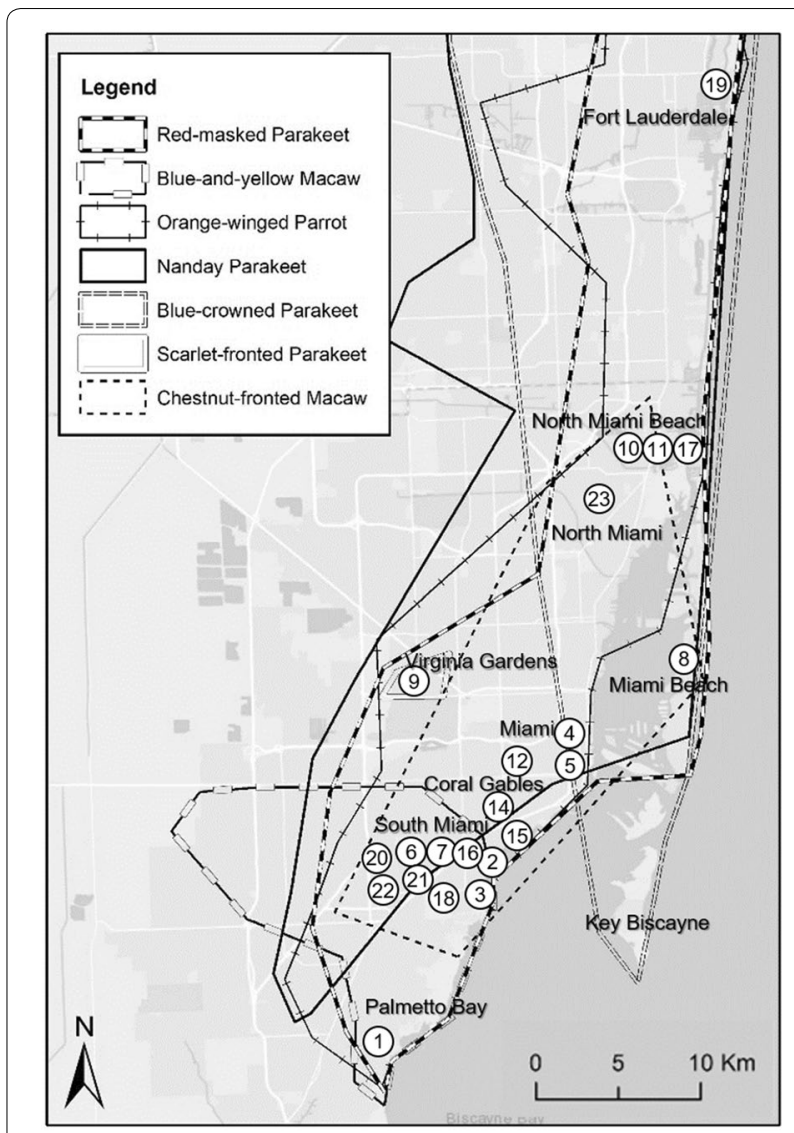

Fig. 2 Geographic ranges of cavity-nesting parrots, and observed nest trees. Numbering of nest trees follows Table 1. Nest trees have been dispersed minimally for display purposes. Geographic ranges are drawn to encompass at least $96 \%$ of observations of each species, ignoring distant outliers. All cavities used are found within the core geographic range of each species

breeding range of cavity-nesters. Budgerigars were once the most common parrot in Florida, but disappeared following boom-and-bust population cycles (Pranty 2001). The greater-Miami area is reported to have the greatest richness of Amazona parrots, but we only found the Orange-winged Parrot breeding (Mori et al. 2017).

Tree cavities, both naturally occurring and excavated by woodpeckers, can be rare and limiting in developed areas (Blewett and Marzluff 2005; LaMontagne et al. 2015; Tilghman 1987). Holes formed by natural decay are rare in Miami due to arboriculture via excessive pruning of trees, and hurricanes destroying naturally decayed boles. Other anthropogenic structures are available for nesting; during our searches we found a large nesting colony of Mitred Parakeets (Psittacara mitrata) nesting in the roof of an apartment building, and recorded 118 Monk Parakeet (Myiopsitta monachus) stick nests built primarily on electrical infrastructure. Some parrots that nest in tree cavities may also breed in anthropogenic structures, such 
as the exotic Rose-ringed Parakeets which will usurp tree cavities but also breed in the putlog holes of an Italian castle (Grandi et al. 2018). Woodpecker cavities in Miami are common, but low cavity supply elsewhere leads to interference competition. Exotic Rose-ringed Parakeets have been cited for outcompeting native cavity-nesting birds in European cities (Strubbe and Matthysen 2009; Newson et al. 2011; Hernández-Brito et al. 2014). Their aggressive usurpation of cavities is suggested to reduce populations of Eurasian Hoopoe (Upupa epops) in Israeli orchards (Yosef et al. 2016). Similarly, exotic parrots in Hawaii have displaced native birds from nest cavities (Runde et al. 2007). A meta-analysis indicated that most of the reports of impacts of exotic parrots in Europe have been anecdotal, followed by non-experimental (such as in our study) and still remain difficult to quantify (White et al. 2019). We did not find evidence in our study of cavity limitation constraining reproduction of parrots, or parrots competing with native birds for nest sites.

Parrot nesting in tree cavities in Miami appears strongly linked to palm snags. All palm snags we recorded contained woodpecker holes, but many parrots are considered weak excavators, and can create entrance holes in soft substrates like termitaria or heavily decayed palm wood (Goodfellow 2011). Arboreal termitaria are not present in Miami, making palm snags the most suitable substrate to excavate or enlarge a cavity entrance. Where Pileated Woodpeckers occur in Miami, they create nest cavities that are sufficient for larger exotic parrots without any secondary enlargement. Pileated Woodpeckers have been demonstrated to use suburban areas, where a significant portion of forest cover and snags are available in public green spaces and yards (Tomasevic and Marzluff 2018). While their disproportionately high use by parrots suggests that cavities created by Pileated Woodpeckers are preferred, Red-bellied Woodpecker cavities are also useable when excavated in the soft wood of palm trees, where they can be enlarged by parrots. Palm snags have been reported as important nest sites for the same suite of parrot species worldwide. Pranty et al. (2010) note that Blue-and-yellow Macaws in Miami nested primarily in royal palm snags but also fan palm (Borassus spp.) snags. In Peru, Blue-and-yellow Macaws nested primarily in palm snags with long stems, morphologically similar to royal palms (Brightsmith 2005; Renton and Brightsmith 2009). In Florida, 57.1\% of 49 identified Nanday Parakeet nest sites were in palm snags (Pranty and Lovell 2011). In Southern California, which shares many of the same exotic parrot species, most parrot nest trees are palms (Garrett 1997). Date palms (Phoenix dactylifera) in Israeli orchards are the primary agricultural nest site for exotic Rose-ringed Parakeets (Yosef et al. 2016).
Other parrot species are reported to breed in palm snags in their native ranges (Berkunsky et al. 2014; Dahlin et al. 2018). Amazona parrots are increasing in population and expanding their range in the southern United States, particularly Florida and California, where palm trees are common (Mori et al. 2017).

In our study, in most cases when parrot eggs disappeared we were not able to ascertain a cause. In one case, the cavity entrance had scratch marks and enlargement suggesting predation by a raccoon (Table 2). We observed several cavities where Eastern Rat Snakes (Pantherophis alleghaniensis) and Corn Snakes (Pantherophis guttatus) had predated passerine nests, which left no visible sign of the predation event afterwards. We were only able to identify these snakes because we discovered them still inside the cavities. In each case when at least one egg hatched, at least one nestling fledged. All total nest failures occurred during the incubation phase. A nest was considered successful if at least one nestling fledged. We did not record any instances of suspected poaching of exotic parrots, but it has been suggested that poaching has contributed to the decline of Blue-and-yellow Macaws in Miami, which are particularly valuable in the pet trade. This species has the highest retail price of parrots present in Miami, with a mean price of nearly $\$ 900$ USD in 1988 (Wright et al. 2001), and advertised prices of ranging from \$1000-4000 USD in 2018.

The Nanday Parakeet is known to be a more common breeding resident farther north along the southeast coast of Florida, and in the Tampa Bay region (Pranty and Lovell 2011). We incidentally noticed a pair of Nanday Parakeets using a Pileated Woodpecker cavity in a utility pole in Bradenton during our study period and included the observation in our study. We were successfully able to inspect one Nanday Parakeet nest in a royal palm at Hugh Taylor Birch State Park in Fort Lauderdale. Ten years prior to this inspection, Pranty and Lovell (2011) reported a nesting attempt of Nanday Parakeets at the same park, in a palm tree. The main breeding population of this species appears to have shifted from Broward to Palm Beach County. At the time of that report, only one of 12 Nanday Parakeet nesting attempts in southeast Florida occurred in Palm Beach County. During the 2 years of our study, $73.5 \%$ of Nanday Parakeet observations in southeast Florida were in Palm Beach County. The Nanday Parakeet is the most widespread cavitynesting parrot in Florida, observed in over one quarter of Florida's counties.

The geographic ranges of all parrots in Miami suggest an urban/suburban habitat association. No parrot species appears to have established a breeding presence within the major natural areas adjacent to urban southeast 
Florida. We inspected nest cavities at several locations within Everglades National Park, Big Cypress National Preserve, Fakahatchee Strand Preserve State Park, and Crocodile Lakes National Wildlife Refuge, but did not find parrots nesting at any of these locations. Urban areas may have more food resources for parrots, including fruiting shade trees such as exotic Ficus species, and many fruit trees cultivated for human consumption, like mangos (Mangifera indica), starfruit (Averrhoa carambola), loquat (Eriobotrya japonica), and tamarind (Tamarindus indica). Exotic parrots in Florida have been documented feeding on fruits, flowers, and seeds of these and many other native and exotic trees common to the urban environment, including gumbo limbo, sea grape, black olive, Australian pine, and various palms (Epps 2007). Additionally, backyard enthusiasts have attracted parrots to feeding stations. Upland forests fragments in Miami present a mix of fruiting tree species, and are present throughout urban parks and private properties (Alonso and Heinen 2011; Giannini and Heinen 2014; Diamond and Heinen 2016). Although a diverse mix of trees are present in hardwood hammock forests, Miami's urban forest may have advantages over the Florida native tropical dry forests. Hardwood hammocks are naturally patchy in distribution, while Miami's urban savanna forms a nearly continuous, if sparse, canopy (Gobster 1994). This urban forest contains of many of the native tree species, as well as hundreds of additional exotic species; tree inventories in Miami-Dade counted over 250 species (Diamond and Ross 2018). The large variety of trees in a tropical city provide resources asynchronously, ensuring an adequate food supply.

\section{Conclusions}

Exotic parrots in Miami do not appear to pose a threat of invading intact natural areas. Parrots have been present in the periphery of these natural systems for decades with no sign of a nascent invasion. Breeding attempts are widespread but less common than most native or exotic birds. They are particularly less numerous than European Starlings, the dominant exotic usurper of nest cavities. They are also less common than the woodpeckers, which excavate sufficient cavities in an urban region to prevent nest site limitation. Other imperiled hole-nesting native birds found in temperate peninsular Florida such as Red-cockaded Woodpecker (Leuconotopicus borealis), Brown-headed Nuthatch (Sitta pusilla), and Eastern Bluebird (Sialia sialis), are absent in Miami limiting the potential for parrots to harm native bird populations (Blanc and Walters 2008). The biotic resistance from nest competition in urban Miami is low, allowing small populations of parrots to persist without interacting with most native species.

\section{Acknowledgements}

We thank nearly two dozen volunteers who assisted in field data collection. We thank the staff of numerous public and managed areas where research was conducted. This is contribution number 926 from the Southeast Environmental Research Center in the Institute of Water \& Environment at Florida International University.

\section{Authors' contributions}

JMD and MSR conceived the idea for this research. JMD carried out most of the field work and analysis, and JMD and MSR have both contributed to the writing of this manuscript. Both authors read and approved the final manuscript

\section{Funding}

Funding for this project was provided by the Florida International University Tropics Program and the Susan S. Levine Trust. The funding body had no role in in the design of the study or collection, analysis, or interpretation of data.

\section{Availability of data and materials}

The datasets used and/or analyzed during the current study are available from the corresponding author on reasonable request.

\section{Ethics approval and consent to participate}

This project was approved by the Institutional Animal Care and Use Committee at Florida International University (IACUC-16-066). At no point in this study did we touch or handle any vertebrate specimen, living or dead.

\section{Consent for publication}

Not applicable.

\section{Competing interests}

The authors declare that they have no competing interests.

Received: 8 May 2019 Accepted: 17 September 2019

Published online: 14 October 2019

\section{References}

Alonso J, Heinen JT. Miami Dade County's environmentally endangered lands program: local efforts for a global cause. Nat Areas J. 2011;31:183-9.

Avery ML, Moulton MP. Florida's non-native avifauna. Manag Vertebr Invasive Species, USDA Natl Wildl Res Cent Symp. 2007. p. 365-77.

Berkunsky I, Daniele G, Kacoliris FP, Díaz-Luque JA, Silva Frias CP, Aramburu RM, et al. Reproductive parameters in the critically endangered blue-throated Macaw: limits to the recovery of a parrot under intensive management. PLOS ONE. 2014;9:1-7.

Blackburn TM, Cassey P. Patterns of non-randomness in the exotic avifauna of Florida. Divers Distrib. 2007;13:519-26.

Blackburn TM, Lockwood JL, Cassey P. Avian invasions: the ecology \& evolution of exotic birds. New York: Oxford University Press; 2009.

Blanc LA, Walters JR. Cavity-nest webs in a longleaf pine ecosystem. Condor. 2008;110:80-92.

Blewett CM, Marzluff JM. Effects of urban sprawl on snags and the abundance and productivity of cavity-nesting birds. Condor. 2005;107:678-93.

Brightsmith DJ. Parrot nesting in southeastern Peru: seasonal patterns and keystone trees. Wilson Bull. 2005;117:296-305.

Cameron M. Parrots: the animal answer guide. Baltimore: The Johns Hopkins University Press; 2012.

Clements SL, Catania SVL, Searcy CA. Non-native species dominate herpetofaunal community patterns in both native and non-native habitat patches in urban Miami-Dade County. Biol Invasions. 2019. https://doi. org/10.1007/s10530-019-01934-w.

Cornelius C, Cockle K, Politi N, Berkunsky I, Sandoval L, Ojeda V, et al. Cavitynesting birds in neotropical forests: cavities as a potentially limiting resource. Ornitol Neotrop. 2008;19:253-68.

Czajka C, Braun MP, Wink M. Resource use by non-native Ring-Necked Parakeets (Psittacula krameri) and Native Starlings (Sturnus vulgaris) in Central Europe. Open Ornithol J. 2011;4:17-22.

Dahlin CR, Blake C, Rising J, Wright TF. Long-term monitoring of Yellow-naped Amazons (Amazona auropalliata) in Costa Rica: breeding biology, 
duetting, and the negative impact of poaching. J Field Ornithol. 2018;89:1-10.

Diamond JM, Heinen JT. Conserving rare plants in locally-protected urban forest fragments: a case study from Miami-Dade County, Florida. Urban For Urban Green. 2016;20:1-11.

Diamond JM, Ross MS. Tree selection and foraging height of wintering Yellowbellied Sapsuckers (Sphyrapicus varius) in an urban environment. Wilson J Ornithol. 2018;130:932-9.

Dorcas ME, Willson JD, Reed RN, Snow RW, Rochford MR, Miller MA, et al. Severe mammal declines coincide with proliferation of invasive Burmese pythons in Everglades National Park. Proc Natl Acad Sci. 2012;109:2418-22.

Doren RF, Jones DT. Management in Everglades National Park. In: Simberloff D, Schmitz DC, Brown TC, editors. Strangers in paradise: impact and management of nonindigenous species in Florida. Washington, DC: Island Press; 1997. p. 267-75.

Dudley J, Saab V. A field protocol to monitor cavity-nesting birds. Res Pap. RMRS-RP-44. US Dep. Agric. For. Serv. Rocky Mt. Res. Stn. Fort Collins, Colorado; 2003.

Epps SA. Parrots of South Florida. Sarasota: Pineapple Press, Inc.; 2007.

Garrett KL. Population status and distribution of naturalized parrots in southern California. West Birds. 1997;28:181-95.

Giannini HC, Heinen JT. Miami-Dade County's Environmentally Endangered Lands Covenant Program: creating protected areas on private lands via financial incentives. Nat Areas J. 2014;34:338-45.

Gobster P. The urban savanna: reuniting ecological preference and function. Restor Manag. 1994;12:64-71.

Goodfellow P. Avian architecture: how birds design, engineer, and build. Princeton: Princeton University Press; 2011

Grandi G, Menchetti M, Mori E. Vertical segregation by breeding ring-necked parakeets Psittacula krameri in northern Italy. Urban Ecosyst. 2018;21:1-7.

Hernández-Brito D, Carrete M, Popa-Lisseanu AG, Ibáñez C, Tella JL. Crowding in the city: losing and winning competitors of an invasive bird. PLOS ONE. 2014;9:e100593.

Hernández-Brito D, Carrete M, Ibáñez C, Juste J, Tella JL. Nest-site competition and killing by invasive parakeets cause the decline of a threatened bat population. R Soc Open Sci. 2018. https://doi.org/10.1098/rsos.172477.

James FC. Nonindigenous birds. In: Simberloff D, Schmitz DC, Brown TC, editors. Strangers in paradise: impact and management of nonindigenous species in Florida. Washington, DC: Island Press; 1997. p. 139-56.

LaMontagne JM, Kilgour RJ, Anderson EC, Magle S. Tree cavity availability across forest, park, and residential habitats in a highly urban area. Urban Ecosyst. 2015;18:151-67.

Luneau MD, Noel BL. A wireless video camera for viewing tree cavities. J Field Ornithol. 2010;81:176-85.

Martin K, Eadie JM. Nest webs: a community-wide approach to the management and conservation of cavity-nesting forest birds. For Ecol Manag. 1999;115:243-57.

Menchetti M, Mori E. Worldwide impact of alien parrots (Aves Psittaciformes) on native biodiversity and environment: a review. Ethol Ecol Evol. 2014;26:172-94.

Mori E, Ancillotto L, Menchetti M, Romeo C, Ferrari N. Italian red squirrels and introduced parakeets: victims or perpetrators? Hystrix. 2013;24:195-6.

Mori E, Grandi G, Menchetti M, Tella JL, Jackson HA, Reino L, et al. Worldwide distribution of non-native Amazon parrots and temporal trends of their global trade. Anim Biodivers Conserv. 2017;40:49-62.

Mutascio HE, Pittman SE, Zollner PA, D'Acunto LE. Modeling relative habitat suitability of southern Florida for invasive Burmese pythons (Python molurus bivittatus). Landsc Ecol. 2018;33:257-74.
Newson SE, Johnston A, Parrott D, Leech DI. Evaluating the population-level impact of an invasive species, Ring-necked Parakeet Psittacula krameri, on native avifauna. Ibis. 2011;153:509-16.

Orchan Y, Chiron F, Shwartz A, Kark S. The complex interaction network among multiple invasive bird species in a cavity-nesting community. Biol Invasions. 2012;15:429-45.

Ouellet-Lapointe U, Drapeau P, Cadieux P, Imbeau L. Woodpecker excavations suitability for and occupancy by cavity users in the boreal mixedwood forest of eastern Canada. Ecoscience. 2012;19:391-7.

Owre OT. A consideration of the exotic avifauna of southeastern Florida. Wilson Bull. 1973:85:491-500.

Peck HL, Pringle HE, Marshall HH, Owens IPF, Lord AM. Experimental evidence of impacts of an invasive parakeet on foraging behavior of native birds. Behav Ecol. 2014;25:582-90.

Pranty B. The budgerigar in Florida: the rise and fall of an exotic psittacid. N Am Birds. 2001;55:389-97.

Pranty B, Epps SA. Distribution, population status, and documentation of exotic parrots in Broward County, Florida. Florida Field Nat. 2002;30:111-50.

Pranty B, Lovell HW. Presumed or confirmed nesting attempts by Blackhooded parakeets (Nanadayus nenday) in Florida. Florida Field Nat. 2011;39:75-110.

Pranty B, Feinstein D, Lee K. Natural history of blue-and-yellow macaws (Ara ararauna) in Miami-Dade County, Florida. Florida Field Nat. 2010;38:55-62.

Renton K, Brightsmith DJ. Cavity use and reproductive success of nesting macaws in lowland forest of southeast Peru. J Field Ornithol. 2009;80:1-8.

Runde DE, Pitt WC, Foster JT. Population ecology and some potential impacts of emerging populations of exotic parrots. In: Witmer GW, Pitt WC, Fagerstone KA, editors. Managing vertebrate invasive species: proceedings of an international symposium. USDA/APHIS Wildlife Services, National Wildlife Research Center, Fort Collins, Colorado, USA. 2007. p. 338-60.

Sementelli A, Smith HT, Meshaka WE, Engeman RM. Just green iguanas? The associated costs and policy implications of exotic invasive wildlife in South Florida. Public Work Manag Policy. 2008;12:599-606.

Simberloff D, Schmitz DC, Brown TC, editors. Strangers in paradise: Impact and management of nonindigenous species in Florida. Washington, DC: Island Press; 1997.

Strubbe D, Matthysen E. Invasive ring-necked parakeets Psittacula krameri in Belgium: habitat selection and impact on native birds. Ecography. 2007;30:578-88.

Strubbe D, Matthysen E. Experimental evidence for nest-site competition between invasive ring-necked parakeets (Psittacula krameri) and native nuthatches (Sitta europaea). Biol Conserv. 2009;142:1588-94.

Tilghman NG. Characteristics of urban woodlands affecting breeding bird diversity and abundance. Landsc Urban Plan. 1987;14:481-95.

Tomasevic JA, Marzluff JM. Use of suburban landscapes by the Pileated Woodpecker (Dryocopus pileatus). Condor. 2018;120:1-13.

White RL, Strubbe D, Dallimer M, Davies ZG, Davis AJS, Edelaar P, et al. Assessing the ecological and societal impacts of alien parrots in Europe using a transparent and inclusive evidence-mapping scheme. NeoBiota. 2019;48:45-69.

Wright TF, Toft CA, Enkerlin-Hoeflich E, Gonzalez-Elizondo J, Albornoz M, Rodríguez-Ferraro A, et al. Nest poaching in neotropical parrots. Conserv Biol. 2001;15:710-20.

Yosef R, Zduniak P, Żmihorski M. Invasive ring-necked parakeet negatively affects indigenous Eurasian hoopoe. Ann Zool Fennici. 2016;53:281-7. 